\title{
PLASMA VISCOSITY AND SUSPENSION STABILITY IN CHRONIC RHEUMATIC DISEASES
}

\author{
BY \\ JOSEPH RACE \\ Devonshire Royal Hospital, Buxton, Derbyshire
}

In view of the results obtained by the determination of plasma viscosity by Harkness and others (1946) it seemed desirable to apply this method to the chronic rheumatic diseases, but owing to difficulties encountered in procuring the apparatus comparatively few tests had been made before the publication of similar trials by Cowan and Harkness (1947).

In the latter paper erythrocyte sedimentation rate figures obtained by the Wintrobe method were compared with the viscosities, and the authors say, "Our results appear to confirm that the viscosity is a more reliable index of clinical condition than the ESR". They add protocols, in some of which the viscosity was abnormal and the erythrocyte sedimentation rate within normal limits despite an obviously active clinical condition.

Previous experience with the Wintrobe technique has shown that it may be grossly inaccurate when the cell volume approximates to the normal level and that normal results may be obtained when the wide-tube method indicates a definite abnormality (Collins and others, 1939).

The results reported in this communication were obtained with a micro-viscometer kindly lent by Dr. Harkness and designed by Mr. R. B. Whittington, M.Sc., of Manchester University, to whom I am also indebted for the construction of the ancillary parts of the apparatus and a nomograph for the rapid calculation of the results.

\section{The Experiments}

The experiments were divided into two series: one with mixed oxalates as the anti-coagulant as recommended by Heller and Paul (1934); and the other in which potassium oxalate was used. With the latter about $0.5 \mathrm{ml}$. of a saturated solution was drawn into the syringe, the piston was moved up and down a few times, and the oxalate was ejected. If the syringes were reasonably tight it was found that a $10 \mathrm{ml}$. syringe added about
$1.4 \mathrm{mg}$. of oxalate per $\mathrm{ml}$. of blood and a $20 \mathrm{ml}$. one not more than $1.2 \mathrm{mg}$. per ml. After the sample had been taken, about $0.5 \mathrm{ml}$. of air was drawn into the syringe, which was then inverted several times to assist admixture. With this amount of oxalate no clotting occurred, and cell shrinkage was reduced to not more than 1 per cent. With dried oxalates local concentration occurs at the interface between the blood and the crystals, and if mixed ammonium and potassium oxalates are used there is a slight tendency to produce haemolysis.

The samples used for viscometric determinations were centrifuged within 30 minutes after transfer to the tubes which have been described by Collins and others (1939), and the suspension stability (S.S.) was read at 15-minute intervals from the time the S.S. tubes were filled from the syringe. This procedure would perhaps be impracticable in a large General Hospital but in the Devonshire Royal Hospital practically all the patients are ambulatory and can be collected in a room adjoining the theatre.

\section{Results}

The results of the series obtained with potassium oxalate as the anti-coagulant are shown in the diagram, the ones in which mixed oxalates were used and those in which the viscosities were plotted against maximum rates being omitted to conserve space; the results were practically the same in both series.

By the method of Collins and others, which is simple and gives results quite suitable for clinical work, the suspension stability figures are corrected to a standard cell volume of 42 per cent. (This and similar methods are inferential, and the direct determination as made by Houston and others (1945) is the most accurate technique yet devised.)

It will be seen that all the samples within the normal limits for the corrected suspension stability (C.S.S.) are well within the normal limits for viscosity suggested by Cowan and Harkness (1947) and that all the samples with a high viscosity also show a diminished C.S.S. Among the samples with a 


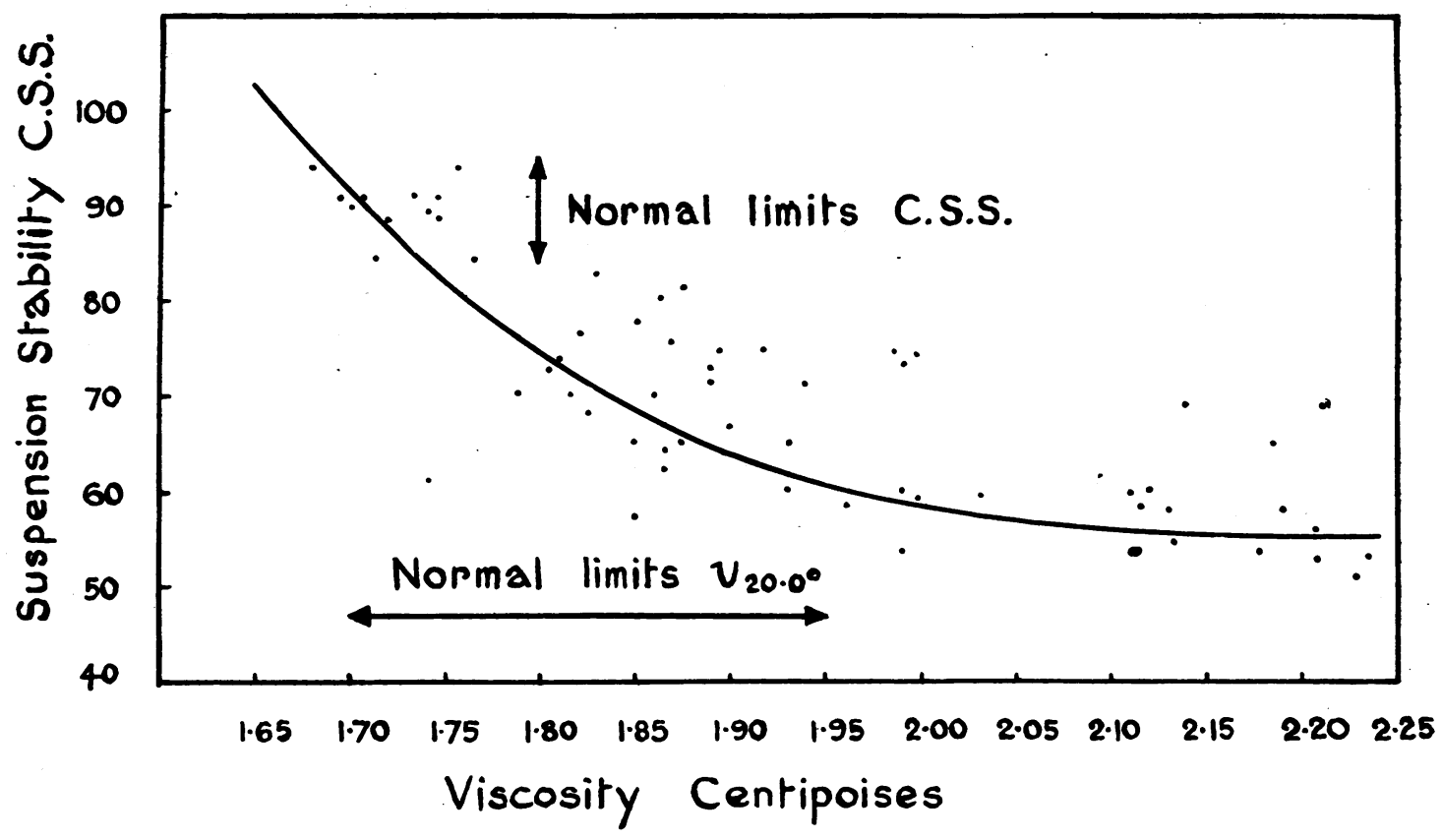

normal viscosity, however, are a considerable number with a low C.S.S., the figures being:

$\begin{array}{lc}\text { C.S.S } & \text { Samples with normal viscosity } \\ 80-84 & 3 \\ 70-79 & 13 \\ 60-69 & 9 \\ 50-59 & 1\end{array}$

All of these showed signs and/or symptoms of some form of chronic rheumatic disease.

Outside the normal limits for viscosity are a number of samples that are abnormal by both methods, but it is quite obvious that the viscosity shows the extent of the abnormality better than is indicated by the C.S.S. figures. This is due to the fact that the 1-hour reading, used for the numerical expression of the C.S.S., approximates to the packed cell volume (P.C.V.), a fault inherent in this method.

Malone has calculated that a red cell occupies about 60 per cent. of the volume of a rectangular parallelopiped just large enough to contain it. When the S.S. reaches 60 per cent. the corpuscles are contiguous in all directions, and any further reduction of the S.S. must be accompanied by packing. If any appreciable reduction occurs after the 60 per cent. level is reached, an increased plasma volume (anaemia) is indicated.

It has been suggested that the maximum rate of fall is a better criterion of the abnormality, and this was calculated in both series of samples by plotting the S.S. readings and drawing a tangent at the steepest portion of the curve. The maximum rates were calculated from the slope of the tangents and the results plotted against the viscosity . The graphs prepared in this way materially reduced the extent of the defect mentioned above and enabled the extent of the abnormality to be expressed numerically. A further improvement will be effected when data are available for the correction of the maximum rates to a standard cell volume.

It is clear, however, that the viscosity, being quite independent of the cell-packing factor, will give a somewhat better indication of the degree of abnormality.

The results of the viscosity and C.S.S. tests have both been attributed to alterations in the plasma proteins but it does not necessarily follow that there should be a high degree of correlation between them. The viscosity is mainly determined by the number of protein molecules and their molecular weight, the electrolytes playing but a minor role, whilst rouleaux formation, the main factor in the S.S. test, is largely the effect of the fibrinogen. This compound, although forming but 3 to 5 per cent. of the total plasma protein, may be responsible for about 80 per cent. of the abnormality in the S.S. figure; whilst albumin, the predominating protein, tends towards increased stability. The albumin acts in opposite directions in the two methods, and in such circumstances a high degree of correlation is not to be expected. 
This is capable of experimental proof. A sample from a case of ankylosing spondylitis (a man aged 31 years who had had the complaint for thirteen years) was divided into two portions, one being oxalated and the other defibrinated. The results were: oxalated sample, viscosity $2 \cdot 120 ;$ S.S. $\frac{1}{2}$-hour 61, 1-hour 51; defibrinated sample, viscosity 1.915 ; S.S. $\frac{1}{2}$-hour 95,1 -hour 81 . As the oxalated sample reached the packed cell volume in 30 minutes, this reading is a better criterion than later ones. The defibrinated sample had dropped but 5 per cent. as compared with 39 per cent. in the oxalated one, although the difference between the viscosities was comparatively small $(0 \cdot 205)$. The removal of the fibrinogen $(0.60$ per cent.) reduced the S.S. by 87 per cent. and the viscosity by only 9 per cent.

\section{Summary}

Contrary to the results of Harkness and others, who found the plasma viscosity test to be a more reliable index of activity in chronic rheumatic diseases than the erythrocyte sedimentation rate as performed by the Wintrobe method, the results obtained with the wide-bore method recommended by Collins and others showed a greater sensitivity and in several cases gave an abnormal value when the viscosity was within normal limits.

The viscosity is more valuable in some cases, as it is not limited by the packing effects of the red cells which normally starts when the cell volume reaches about 60 per cent.

It is important to correct sedimentation rates for the cell volume, and the corrected maximum rates are preferable to those recorded at a single arbitrary time interval.

\section{REFERENCES}

Collins, D. H., Gibson, H. J., Race, J., and Salt, H.B (1939). Annals of the Rheumatic Diseases, 1, 333. Cowan, I. C., and Harkness, J. (1947). Brit. med. J., 2, 686.

Harkness, J., Houston, J., and Whittington, R. B. (1946). Ibid., 1, 268.

Heller, V. G., and Paul, H. (1934). J. Lab. clin. Med., 19, 777.

Houston, J., Harkness, J., and Whittington, R. B. (1945). Acta tuberc. scand., 19, 153.

Malone, W., Unpublished M. D. Thesis.

\section{Viscosite et Stabilite Colloidale du Plasma dans les Affections Rhumatismales Chroniques \\ RÉSUMÉ}

Contrairement aux résultats de_Harkness et de ses collaborateurs, qui ont trouvé que la mesure de la viscosité du plasma constitue une indication de l'activité des affections rhumatismales chroniques plus fidèle que le taux de sédimentation globulaire obtenu par la méthode de Winthrobe, les résultats obtenus avec la méthode à tube large recommandée par Collins et ses collaborateurs ont montré que cette méthode présente une plus grande sensibilité et dans plusieurs cas les chiffres obtenus étaient anormaux même alors que la viscosité restait dans les limites normales.

Dans certains cas la viscosité est préférable car elle n'est pas limitée par l'agglomératoin des globules rouges qui commence généralement lorsque le volume des cellules atteint environ 60 pour cent.

Il est important de corriger les taux de sédimentation en fonction du volume cellulaire, et les taux maximaux corrigés sont préférables à ceux que l'on obtient après un seul intervalle arbitraire. 